\title{
Who is My Neighbour? Effective Altruism, the Good Samaritan, and the Opportunities of the 21 st Century
}

\begin{abstract}
This article is an attempt to take a philosophical approach to the powerful text of the parable of the Good Samaritan in light of the opportunities of the 21st century. The text starts with presenting various ways in which modern Christians can answer the question "who is my neighbour?" and comparing them to the typical response assumed by the effective altruism movement. On the basis of one of the interpretations, a framework is offered for determining whether the beneficiaries of help in the cause areas of effective altruism can be categorized as neighbours. For this inquiry, the so-called "less demanding" interpretation is chosen since prima facie it does not seem to provide a justification for the thesis that all people fall under the category of neighbour. This article claims that due to the development of technology and research as well as due to the global increase in wealth, the less demanding interpretation of the parable of the Good Samaritan conceives of people distant in space as neighbours but not of animals and not of the unidentified people distant in time. It is argued that Christians have moral reasons and ways to support treating animals as neighbours, as well as to support cooperation for the sake of protecting future humanity, at least from the threats that are of human origin.
\end{abstract}

\section{Introduction}

Effective altruism (EA), a new approach to charity, is attracting many Christians, as it promises to provide evidence-based, effective solutions to those problems that are traditionally associated with Christian concerns. At the same time, some ideas of EA (as well as the philosophical and anthropological assumptions that dominate the movement) may give rise to doubts as to whether or not it should be supported by followers of Jesus.

This article is a philosophical attempt to contribute to the dialogue between EA and Christianity. The starting point is the parable of the Good Samaritan and the lawyer's question: "Who is my neighbour?" The parable starts with the lawyer's request for Jesus to tell him how one can inherit eternal life. The lawyer, as an expert in God's Law, knew the answer already and wanted to test Jesus (Luke 10:25). Jesus asked the lawyer to repeat the Law and the lawyer answered: "You shall love the Lord your God with all your heart, and with all your soul, and with all your strength, and with all your mind; and your neighbour as yourself" (Luke 10:27). Jesus appreciated this answer: "do this and you will live" (Luke 10:28). The answer was not a great revelation for the lawyer, as The Greatest Commandments (Matt. 22:37-39) were a fundamental component of his religion . His next question, which nowadays does not have a fixed answer, was a real 
philosophical challenge: "Who is my neighbour?". Supposing I am to love my neighbour as myself, it would be practical to know who my neighbour is.

This question is indirectly answered by EA and this, together with its other commitments, brings us to three areas on which, it argues, our charity efforts should focus. In each of these areas a different group is supported: people living in extreme poverty, animals, and people living in the far future. In the beginning, I will discuss the importance of the lawyer's question and explain how it can be answered by EA. In the next part, I will present some arguments that can be provided in order to show that Christians do not have moral duties towards people in distant lands. Then, I will present the meaning of Jesus's answer which - instead of selecting specific criteria for the neighbour - changed the perspective and asked his followers rather to be neighbours themselves. In the next part, I will try to extract the features of the neighbour from the parable and propose two interpretations, from which I will choose the less demanding one for a framework of further analysis: the "neighbour" is a person that I can personally affect. I argue that in our times, even this less demanding interpretation means including all people in the category of "neighbour", although in the past the range of the notion was smaller. Its broadening was caused by the increase of our power. Following this, on the basis of the same framework, I will argue that according to the proposed interpretation of the parable, animals are not neighbours, but we have sufficient knowledge and power to treat them as such. Finally, I propose that those living in the far future also are not our neighbours in the framework of "the less demanding interpretation", and it also seems we have neither the knowledge nor the power to treat them as neighbours. However, they are not to be neglected. Their vital interests will be met by meeting our duties to creation, our duties towards those who already exist and by intergenerational solidarity, all of which are passed from generation to generation.

\section{Effective Altruists' Neighbours}

The parable of the Good Samaritan (Luke 10:25-30) is one of the most influential stories ever told. For centuries, it was an important part of the Christian message concerning charitable actions, as well as the range of moral concern. Although it is set in ancient times, it is universal and continues to provide new inspiration for contemporary thinkers. In this parable, Jesus provided new insight into the Old Testament's notion of 
"neighbour", which effectively changed the understanding of God's second greatest commandment "Love your neighbours as yourself" (Mark 12:31). The lawyer asked a question that naturally emerges when we deal with obligations towards others who are only vaguely captured by the reference "neighbour". By asking "who is my neighbour", one is asking: who am I supposed to love (and consequently, who not)? To translate this into the language of contemporary ethics: towards whom do I have moral duties, and whom or what can I disregard?

The answers to those fundamental questions regarding our moral obligations towards others, which are given by intellectuals supporting EA, are of utilitarian origins as both the idea and movement were developed within a utilitarian framework. Utilitarianism, as compared to the morality of contemporary societies, tends to broaden the range of moral duties (and so includes more and more beings as objects of morality) in a counterintuitive way. The answer to the question posed by the lawyer is given by the principle of equal consideration of interests: the range of our moral duties extends to all beings holding moral status, which means that they are at least capable of suffering or their interests or preferences can be influenced by our actions. Identical interests should be weighted equally, regardless of morally irrelevant factors like race, gender, sex, species, or geographical distance. According to one of the fathers of EA, Peter Singer, we should include both people in distant countries and animals in our moral decision-making and weigh their interests from the perspective of an impartial observer: as equal to the similar interests of others, including ourselves. Nick Bostrom and Toby Ord made an even stronger, although controversial ${ }^{1}$ claim to extend our moral duties to the far future, unidentified interests-bearers. ${ }^{2}$ This kind of broadening of the circle of moral duties ${ }^{3}$ is for Ord "a crucial next step in the ongoing story of humanity's moral progress". ${ }^{4}$

EA selected its main cause-areas - the problems it is trying to resolve. These should be addressed first on our path to making the world the best place possible. Among them are famously: the eradication of extreme poverty, the elimination of animal suffering in factory farms, and the prevention of existential risks for humanity. ${ }^{5}$ The priority for those groups in

1 Singer, The Most Good, 170-175.

2 See Ord, Precipice, 44-46.

3 Cf. Singer, Expanding Circle.

4 Ord, Precipice, 44.

5 CEA, "Handbook," 8. 
these cause-areas is the outcome of rational, evidence-based reasoning, and not a spontaneous surplus of love.

Are these answers compatible with the Christian understanding of being a neighbour? Reflection on the understanding of the category of neighbour in relation to the cause areas of EA is important for Christians interested in the movement. Good arguments for discovering that more beings are neighbours would motivate Christians to show their love to them.

The cause areas are those chosen on the basis of three categories: scale, tractability, and neglectedness. ${ }^{6}$ For the purpose of this paper, it is important to highlight the final point. If an area is neglected, it means either very little or no resources have been used in order to effectively solve the related issues. In this case, one may be surprised that the eradication of extreme poverty is considered "neglected". We have the Sustainable Development Goals of the United Nations, many organisations run by various churches, overseas aid from special funds of the most affluent countries, and rich philanthropists all addressing poverty. Yet, according effective altruists, it remains a neglected area. And although there is currently progress, the striking reality is that around $10 \%$ of the world's population still live in extreme poverty. ${ }^{7}$. If it is a neglected area of charity, then, considering the number of Christians, it must also be neglected by them. Can we say that humanity, and especially Christians, do not see the poor in distant lands as their neighbours, or see them as neighbours whose needs are of a much smaller importance than those of their geographically closer neighbours? The question has a practical nature, but the theoretical reasoning provided in this article suggests how Christians should respond to the problem of poverty eradication.

\section{Christian Love and Overseas Aid}

There is a common agreement that people are equal. Nowadays, it is a moral assumption and a starting point for further argumentation. This postulate does not imply full equality in every area, especially in the category of the distribution of wealth. However, the extreme global inequalities present in this last respect suggest this postulate is not taken seriously enough in our global society. Taking a global perspective, we can see that some people live in extreme affluence, whereas others have literally nothing and

7 Wydick, Shrewd Samaritan, 39. 
are threatened with starvation or easily preventable diseases. ${ }^{8}$ There is a substantial inequality in wealth, access to health services, education, and housing, etc. This is a massive injustice.

What can also be observed in everyday situations is that people are more willing to repair injustices that are close to them rather than far away, even if there is an extreme disproportion between these two kinds of injustices and even if people in distant countries might benefit much more from the same amount of money donated. ${ }^{9}$ Even more can be said: a tendency to favour any, even the least important, wishes of the nearest (and oneself) rather than the crucial, vital interests of the neediest does not seem to be uncommon. ${ }^{10}$ But before claiming that some people are neglecting their duties, it is appropriate to ask if supporting those people who are geographically distant should really considered an obligation for Christians.

There is a considerable amount of well-known literature encouraging Christians to fight extreme poverty. There are examples of saints and church documents to support the idea that Christians should struggle to help eradicate extreme poverty. Finding the arguments against helping the poor in Christian thought is much more difficult. However, the belief that Christians are not obliged to help the poor in distant lands can be supported by certain philosophical, social, and even theological arguments. To grasp the picture, some of them will be presented.

Some philosophers highlighted theoretical problems with Christian love. According to German philosopher Nikolai Hartman, love of unknown, remote people (Fernstenliebe) is the highest value; it was discovered only recently in the modern era and is not of Christian origin. ${ }^{11}$ Christian love, which he calls "brotherly love" or "neighbourly love", "places one's own ego on a level with that of others, concerning itself merely with those who are nearest at hand, those accidentally present, with the narrow circle of those, who are within reach". ${ }^{12}$ Another German philosopher, Max Scheler, tended to see the love of mankind (humanitas) as a modern rebellion against Christian love, powered by a hatred towards God and tradition. ${ }^{13}$ From these opinions, one could conclude that love for all people is not a Christian approach.

8 Sider, Rich Christians, 3-40.

9 MacAskill, Doing Good Better, 28.

10 Hallett, Priorities, 2-3.

11 Hartman, Ethics, 311-331

12 Ibid., 269.

13 Scheler, Sympathy, 2007. 
An argument against supporting the poor in distant lands can also be developed on the basis of the interpretation of the influential concept of the ordo caritatis, as presented by St. Thomas Aquinas in his Summa Theologica. ${ }^{14}$ Aquinas presented guidelines for rational charitable actions, which were later developed by Christian thinkers. The ordo caritatis is a set of reflections on rational Christian love. It gives guidelines in complicated situations regarding charitable actions, for example, how to use limited resources in the event of too many potential beneficiaries for available assistance. ${ }^{15}$ Alternatively, it can be interpreted as a rule of favouring relatives over non-relatives and those in geographic proximity over distant people. This is not just an abstract theory as this framework shapes the real world. For example, in a debate about accepting the relocation of refugees from Southern Europe to Poland in 2015, a prominent politician opposing the idea said: "We must look for another principle, a principle that moderates this radicalism. Well, there is such a principle - that is, ordo caritatis the order of mercy, love. And within this principle: the closest are first, the family, then the nation, then others". ${ }^{16}$ The politician then mentioned that the ordo caritatis does not exclude extending help to those people from outside the circle of the nation, but this help is conditioned by the well-being of the Polish people. Only the quoted section of his speech gained the attention of the media. Even if the concept of ordo caritatis does not, in principle, support the idea that geographically distant people should not be helped at all, it does seem that focusing on the order of potential beneficiaries, rather than the greatness of need, makes enough room for excuses so as to lead to neglecting the very vital interest of distant people while supporting the trivial ones of our relatives and selves. Emphasising only the order of beneficiaries is by no means a full picture of ordo caritatis. Thomas himself said that the circumstances matter in the assessment: "because in certain cases one ought, for instance, to succour a stranger, in extreme necessity, rather than one's own father, if he is not in such urgent need". ${ }^{17}$

14 ST, ii-II, q26.

15 Bartoszek, "Odpowiedzialność, 59.

16 "Musimy szukać zasady innej, zasady, która by moderowała ten radykalizm. Otóż taka zasada istnieje - to jest ordo caritatis - porządek miłosierdzia, umiłowania. I w ramach tej zasady: najpierw są najbliżsi, rodzina, później naród, później inni.” Translation mine. See Onet, "Mocne wystąpienie."

17 ST, ii-II, q31 a.3. 
There are also theological arguments, as scripture can be interpreted in many places as limiting love to geographic proximity or even to the people of our nation. As an example, one may read Mark 7:24-30, when Jesus honoured the Syrophoenician woman's faith. Jesus told the woman: "First let the children eat all they want," and then he said, "for it is not right to take the children's bread and toss it to the dogs." Equally, in the interpretation of the Parable of the Good Samaritan the emphasis can be placed not on universal love, but on other aspects of the Samaritan's help. These include his rationality since the Samaritan prudently applied the resources he had. But the fact that he possessed resources in the first place was an effect of his life model. This model was not that of a person focused on helping everyone he could affect - as for the substantial part of his time, the Samaritan was earning. Practising caritas - helping the ones in need - was not the essence of his life. ${ }^{18}$

The actual practice of Christian help can also be a subject of investigation. It appears to be supporting "discrimination" on the basis of distance: when it comes to giving, more resources are donated to the secondary needs of local Christian communities than to overseas aid, which addresses people's basic and existential problems.

Moreover, the common-sense understanding of the word "neighbour" in English may lead to the conclusion that this basic commandment is about the people near to us.

In contrast to this, I argue that excluding far-away people from "neighbours", which can be also called discrimination on the basis of distance (geographical distancism), is not the obvious indication as to whom one should consider to be an object of love in the rule "love your neighbour". This is not to deny that these selected arguments supporting the thesis that Christians are not obliged to help the poor in distant lands should all be treated with proper respect and caution. In this article, however, there is no room for the discussion they all deserve.

\section{Jesus and Utilitarian Reasoning}

One more important remark must be added. Although EA does not necessarily presuppose utilitarianism, ${ }^{19}$ during the process of becoming acquainted with EA one will encounter utilitarian thinking. There are some schemes which utilitarian thinking favours. For example, a common utili- 
tarian response to the question "who is an object of my moral concern?" would include a catalogue of the morally relevant and preferably measurable features of such a being. These features are meant to make ethics more precise; they also provide the chance to reasonably include into moral considerations some beings that were not previously the obvious objects of moral concern. But it must be noted that a catalogue of that kind may also give reasonable grounds to reject the moral status of certain beings that were previously considered. An immense responsibility is placed on the philosopher who makes an attempt to lay down criteria of moral concern as he provides a basis with which to divide the world into two categories: with moral status and without it. For many beings, this is a life-or-death decision. It must also be noticed that the thinkers inspired by Christianity are often involved in this kind of thinking, which means looking for a set of features that a being should have in order to be perceived as a moral object (and also to exclude other kinds of beings, like animals, which do not belong to a species that has a rational nature).

To search for the criteria which a being requires to be considered of moral value is to take the path of the lawyer who asked Jesus the question of who his neighbour is. Jesus' answer was radically different and went far beyond the limits of the question of his adversary. Jesus answered with a parable:

"A man was going down from Jerusalem to Jericho, and he fell among robbers, who stripped him and beat him, and departed, leaving him half dead. Now by chance a priest was going down that road; and when he saw him he passed by on the other side. So likewise a Levite, when he came to the place and saw him, passed by on the other side. But a Samaritan, as he journeyed, came to where he was; and when he saw him, he had compassion, and went to him and bound up his wounds, pouring on oil and wine; then he set him on his own beast and brought him to an inn, and took care of him. And the next day he took out two denarii and gave them to the innkeeper, saying, 'Take care of him; and whatever more you spend, I will repay you when I come back. Which of these three, do you think, proved neighbor to the man who fell among the robbers? He [the lawyer - J.S.] said, 'The one who showed mercy on him.' And Jesus said to him, 'Go and do likewise.'” (Luke 10:30-37, RSVCE)

Instead of providing a list of features a being should possess to make it capable of deserving our love, Jesus showed us the attitude that one should have to call oneself a neighbour. Jesus said: be neighbours yourself. An example of that approach was given by the Good Samaritan. He was not calculating, and he did not consider whether the wounded man deserved his loving action; he simply acted out of love. What seems to have surprised the 
lawyer, and may still be surprising for the contemporary man, is that instead of providing a specific answer to the question "who is my neighbour?" or "to whom do I have moral duties?", Jesus seems to have redirected our thinking to the question "how can I be a neighbour?", or "what shall I do to 'go and do likewise?". Since EA is a contemporary attempt to reflect upon the method of benevolent acts in the light of philosophy and research, it is not surprising that some Christians may find it to be inspiring.

As it is, the parable of the Good Samaritan and EA exhibit further parallels: the Samaritan seemed to apply some of its guidelines practically in order to help the wounded man in the best way possible. He sacrificed both his time and money, but in the latter case, he trusted the specialist (referred to in the Parable as the innkeeper) instead of performing certain actions himself. As a result, some of his loving acts were done personally, but indirectly. What is more: there is a remark that the Samaritan checked the effectiveness of the innkeeper substituting him - he promised to return to ask after the condition of the wounded traveller, and also offered to be more generous and provide resources to meet unexpected costs after the evidence-based verification.

\section{Distant People as Neighbours}

Jesus' answer to the lawyer tells us that we are supposed to think of how to be neighbours rather than look around and ponder who deserves our love and who does not. That guideline could be enough for a rule of practical reasoning on the individual level.

It seems that on the basis of the Parable of the Good Samaritan, another view on the response to "who is my neighbour" is possible. There is a way to find an answer that seems to make Christian love better informed and suits the need for dialogue with contemporary lawyers. The proposed framework to look for criteria of the neighbour contains the features of the recipient of the Samaritan's help. These will be used to see if people in distant lands, animals, and future unidentified beings can be considered neighbours.

I want to suggest two interpretations of how the parable structures our views about who our neighbour is. The first interpretation is that it argues that our neighbours are simply everyone on the planet, as the distinctions that were typically used to determine who is one's neighbour are shown to have become irrelevant. Many theologians are of the opinion that through the parable of the Good Samaritan, Jesus wanted to say that "neighbours" 
are all of the people around the world. ${ }^{20}$ If this is correct, those Christians who believe that the maxim "love your neighbour" is the fundamental principle of charity should not allow geographical closeness to dictate who benefits from their charitable actions.

The parable of the Good Samaritan was told during a time when most Jewish people did not recognise the Samaritans as their neighbours, even though they were living in the same area. The two groups hated each other. Jesus' teachings had to be difficult for the ancient societies, which were (generally) not able to broaden their circle of moral care beyond their close social relations. As Bruce Wydick explained it, "Jesus pushed the concept of 'neighbour' about as far as possible with his first-century Jewish audience (...) the concept of 'neighbour' was generally limited to one's local network of extended family and friends" and eventually other members of the nation. ${ }^{21}$ The parable can be interpreted as indicating that every person is our neighbour, even the ones who exist in our imagination as mere numbers, and thus the circle of moral care (or the circle of love) should be broadened to include all people. The practical conclusions of this reasoning might be unfamiliar and very demanding for people of all the times, and thus as hard for them to accept as Jesus' teachings were for the people in the first century, who were also called to abandon their lifestyle.

\section{The Less Demanding Interpretation}

However, another interpretation is also possible and, at first sight, less demanding. It may suggest that the Christian understanding of neighbour can be limited in a way that justifies favouring the nearer over the neediest. Therefore, this possible interpretation is a subject of special focus in this article. One can argue that our neighbour is anyone whom we can personally affect. This conclusion can be derived from what the parable tells us about the object of the Samaritan's action. The Samaritan helped "the wounded man" whose ethnic membership was not stated. As a result, we cannot say for sure if the traveller who was attacked by the robbers was a Jew or not (although it seems that the priest and the Levite did not even check). It is neither stated that the Samaritan had a personal relationship with the victim of the robbers nor that he was capable of entering into a dialogue with him. This indicates that ethnic membership is not a morally relevant factor and also shows that the object of a merciful action does not

20 See e.g. Benedict XVI, Deus Caritas Est, and Krawczyk, "Nakaz."

21 Wydick, Shrewd Samaritan, 19. 
have to be in any relation with us prior to our recognition of his need. All we know about the man is that: (1) he required help, (2) he was an adult male human being who was seen by the Good Samaritan, (3) and that he was within range of the Samaritan's action (the Samaritan himself could do something to help). Also, it appears that the age and gender of the victim were accidental, but the species is not. Limiting the circle of moral concern to adult human males would be in contrast with the whole teaching of Jesus, whereas if Jesus decided to insert an animal into this parable instead of a human being, that would be a great novelty in his teaching. Thus, it might be concluded that a neighbour is a human being whom we can personally affect.

The next step in this reasoning is to link the mentioned features of the neighbours with the rule that neighbours are those whom we are supposed to "love as ourselves". This shows that our moral duties extend to all those whom we can affect and help. From this statement, it seems that we need to recognise and understand our abilities and power in order to determine who our neighbour is. If this is a correct form of reasoning, being a neighbour is not some objective property of beings, nor is it a property acquired once and forever.

I call this interpretation the less demanding interpretation in order to contrast it with an interpretation which simply broadens the range of our moral duties to all people. It says we should only consider the people whom we can personally affect. It opens ways to silence the conscience in the instances of some people that suffer. As it seems many people believe they can effectively affect only those people who are geographically close, this interpretation can be understood as a theoretical support for framing our obligations according to our natural tendency to help the people near us, to prefer supporting our family or people from our social surroundings, and to favour small developments in our local community (new museums or better heating for the church) over eradicating the extreme poverty of numerous people living in distant lands. Rather than being the outcomes of philosophical and theological debates alone, natural tendencies and commonly held beliefs are probably a piece of an answer to the question of why wealthy Christians and extreme poverty exist at the same time. 


\section{The Less Demanding Interpretation in the 21st Century}

The second interpretation of the parable seems to be less demanding, but it will be argued that even this interpretation does not support framing our charity actions according to our natural tendency to favour those who are geographically close to us, at least nowadays.

At the same time, it seems that in the past this interpretation supported favouring those who were geographically close, but it was not an instance of geographical distancism. Rather, it is a fact that for the past generations, possibilities were different. People had less power to affect others and were far less aware of the situation in places outside of their communities. They did not (as we often do) hold in their pockets immediate access to the news from around the world, potentially all of human knowledge, and a great selection of funny cat pictures.

In the past, to be able to affect others, an ordinary person needed to be able to meet them physically. The range of people who could be affected was limited by the distance one (or one's deputies) could personally travel. Over the ages, various developments made it possible to travel further, even to the most abandoned areas of the world, but physical distance remained a problem that limited our ability and power to help. People who were willing to help the poor from distant lands were also not in the Samaritan's situation, as he knew how to efficiently help the wounded man (he knew, for instance, whom he could pay in order to make the situation of the suffering man better). Further, the problems of people living in extreme poverty (as well as extreme poverty itself) as a problem are simply more complex than the situation of the attacked traveller from the parable. For years, although a considerable amount of money was spent on giving aid to people in distant countries, we barely had an idea of what could help them in an effective way. Some attempts to eradicate extreme poverty are claimed to do more harm than good, and do so at the cost of precious resources. ${ }^{22}$ Alleviating domestic poverty has become easier as we have better understood it, and that understanding has allowed us the chance to provide effective help. In the case of poverty and the problems of people in distant countries and of different cultures, wealthy nations used to speculate, project their best solutions, and maintain a more or less paternalistic approach. The scientific approach to this problem, especially including randomised controlled trials, made effective help more likely. ${ }^{23}$ It is a fairly recent, although not fully

22 See e.g. Easterly, White Man's Burden, and Leszczyński, Eksperymenty.

23 MacAskill, Doing Good Better, 7-11. 
uncontroversial, invention. ${ }^{24}$ Also, over the past decades, affluence has not been very common: there have been affluent people, but they have been surrounded by poverty. The level of affluence, especially in the wealthiest countries, has no precedence in history. In the words of Peter Singer, numerous people in the most affluent countries are better off than King Louis XIV. ${ }^{25}$ The morally significant difference is that a king was only one person, and now we have millions of wealthy people. Our ancestors had to struggle for their lives and for their families; often, they had very limited resources to support even the closest relatives. We have much more power, and this power is necessary to help people in extreme poverty. What would the Good Samaritan have done for the man without his horse, money, or knowledge of the inns that the wounded man could be helped at?

The world has changed, and our power has increased. Nowadays, global connections make it possible to personally affect people located all around the world. What is more, people from the most affluent countries are more aware of that which creates opportunities for them to become "Good Samaritans". Of course, one should neither underestimate the negative side of globalisation nor the growth of the power of the wealthy. The most obvious way wealthy people affect others in distant countries is pollution, but there are many other ways, bringing both good and harm. For example, in recent years, there has been a rising awareness as to how common it is to use another's misery to get wealthier by supporting, consciously or not, the evil structures exploiting people. However, due to the increase of power, citizens of the most affluent countries have enough resources and technical possibilities to provide help to the poor in distant lands.

We can now also identify the needs of nearly every person in the world, thanks to the media and the internet. Traveling and transporting goods are both becoming cheaper and cheaper. Technology allows us to affect many people around the world instantly with just few a clicks. As Benedict XVI said, globalisation placed at "our disposal numerous means for offering humanitarian assistance to our brothers and sisters in need, not the least modern systems of distributing food and clothing, and of providing housing and care." 26

Finally, the development of charity research, as well as the various improvements of many charity organisations, allow us to help more people whose distant locations would have made such assistance impossible a few

24 See Leszczyński, Eksperymenty. esp. ch. 4.

25 Singer, Life, 9.

26 Benedict XVI, Deus Caritas Est, 30. 
years ago. We can help in an effective way as we are more acquainted with which actions help people in extreme poverty who are within range of our actions.

Since geographical distance no longer strongly limits our abilities to affect and help people across the world, those who are geographically far away must also be called our neighbours, and so the term "global neighbour", as used by Wydick, seems justified. ${ }^{27}$ We are to love our global neighbours as we love ourselves. Taking this seriously would lead to substantial changes in the lives of contemporary Christians and could lead them to internalise at least some of the principles and practical solutions that have been developed by the intellectual efforts of EA. However, does the parable of the Good Samaritan provide a potential for Christians to find a basis to support other cause areas of EA as well?

\section{Animals as Neighbours}

For effective altruists, the suffering of animals morally matters. The severe and increasing amount of easily preventable animal suffering, together with the very little concern expressed by humans and the relatively small resources distributed to prevent it, has made the elimination of animal suffering one of the priorities of EA. The proposed line of reasoning offered by the less demanding interpretation of the Parable of the Good Samaritan does not allow for the understanding of animals as neighbours. If this reasoning is correct, Christians are not obliged to love animals as themselves and the elimination of animal suffering is not a priority. Yet this does not mean they can or should be indifferent to the suffering of animals. The arguments concerning prioritising the elimination of animal suffering in Christian charity require a different framework.

Among pro-animal philosophers, there is a major debate about the impact that Christianity has had on the way our culture perceives animals. Both the desacralisation of nature and the replacement of the ancient animate-inanimate division with a modern version based on consciousness are seen as the roots of our mistreating animals. And both are also seen as having a Christian origin. ${ }^{28}$ Although these theses can be rejected, it is undeniable that the concept of factory farms was invented in Western culture, which was developed on the basis of Christian values. A large part of scientific development is also enabled by animal suffering. Also, according

27 Wydick, Shrewd Samaritan, 19.

28 See for example Singer, Animal Liberation, 271-293. 
to Charles Camosy, for some Christians, the issue of taking animal rights seriously is a part of the cultural conflict with atheism. Animal rights activism is now being associated with a challenge to their fundamental Christian beliefs - specifically regarding God and the value of human life. Therefore, a rejection of the concern for animals is seen as a way to defend their faith. In consequence, they strongly oppose taking animals into moral consideration. ${ }^{29}$ Utilitarianism, on the other hand, harbours extensive concern for animals. There are many kinds of utilitarian arguments to the effect that we should consider animals in our moral decision-making as they have at least one morally relevant feature: they can feel pain. Moral duties towards animals have also been acknowledged in a non-utilitarian way by philosophers who were inspired by Christian thought, such as Andrew Linzey and Charles Camosy. ${ }^{30}$

The less demanding interpretation of the parable allows us to include all people in our moral decision-making. I mentioned that, on the basis of Jesus' overall teaching, it seems plausible to claim that species matter in this interpretation of the parable, and therefore animals are not neighbours. The person that was helped by the Good Samaritan was certainly a human being.

As a potential objection to this interpretation, it can be mentioned that Jesus' teachings were tailored to the sensitivity and capabilities of the people living in ancient times. The Bible never calls animals neighbours. We know that not every possible moral position could have been invoked during biblical times. We can only speculate as to how the parable explaining the notion of neighbour and portraying the Samaritan saving a wounded wild animal would have affected Jesus' disciples.

As was mentioned in the initial sections of this article, Jesus' answer was not a set of criteria, but rather a call to be a neighbour oneself. Thus, regardless of our personal stance on the previous reasoning about whether animals are neighbours or not, all of us can ask if we can be neighbours to animals and what this would mean. The opportunities of the 21 st century have significantly affected the way in which we can approach animals, in a similar manner to the changes in our relations with people located around the world. We affect animals in many ways; by climate change, by our direct actions, and by our dietary choices. And here, just like with people in need, we tend to be arbitrary in our concern. We show love to some animals we encounter, but there is little care for the animals we put into our mouths.

30 Linzey, Animal Theology; Camosy, Love of Animals. 
Would you agree to torture the animal that you can see for the sake of the best lunch ever? I think not. But our meat-based lunches in the first decades of the $21^{\text {st }}$ century nearly always mean a lot of suffering for animals.

The development of ethical reflection and the emerging awareness of the needs of animals enable us to be neighbours to them. Being a Good Samaritan to animals would certainly mean something different than being a Good Samaritan to people. It is for science to tell us what animals' needs and capabilities are. By knowing them better, we can also modify our attitudes towards them.

For utilitarian philosophers, animals should be considered in moral calculations because of their ability to feel pain. For Christians, even if animals cannot be considered neighbours, their needs can be recognised and helped - their pain cannot just be ignored. Christians have good reasons to be neighbours to animals even if, on the basis of the Bible and the parable of the Good Samaritan (using its "less demanding interpretation"), one would be convinced that animals cannot be recognised as neighbours. And potentially these reasons (and Christian solutions) may protect animals even more strongly than the mere focus on their ability to feel pain. After all, by noticing the intrinsic value of animal life, or formulating human duties towards animals on the basis of a "covenant that should mirror God's creative love", 31 they may protect animals in a host of circumstances going beyond pleasure and pain, like protecting them from being killed, not only in a cruel way but also painlessly or securing the biodiversity of creation.

\section{Future People as Neighbours}

Many effective altruists take it as a given that humanity should prioritise existential risk prevention and thus, in a sense, prioritise the far future. In this section, on the basis of the less-demanding interpretation of the Parable of the Good Samaritan, I argue that those living in the far future cannot be captured by the term "neighbour", and that neither can we treat them as neighbours in a way analogical to contemporary, living people and animals. I will also indicate that there are some moral obligations that have arisen in the Christianity ethical tradition which secure the well-being of those living in the far future.

The fact that effective altruists often assign considerable weight to the well-being of future people may discourage some Christians from supporting EA. Placing such a strong emphasis on the well-being of future 
people - and all future beings - is a characteristic of consequentialist views. These views are focused on the outcomes of actions. We can rationally expect that some (indeed most) of our actions will also have consequences extending to those people who do not exist now. This is assumed in many of our everyday choices. For example, the decision a young couple makes regarding where to live has an impact on their unborn, unplanned children, grandchildren, etc. Young couples normally consider their future children while making housing decisions. How far should this thinking extend? Should they also consider the children of their children and the children of their (geographical) neighbours from both the old and new location, or maybe from all possible locations?

For Nick Bostrom, we should consider the people potentially living on the Earth five billion years from now - as long as it is habitable. Essentially, his reasoning is that we should prioritise existential risk prevention over other problems that have affected the development of EA. ${ }^{32}$ Bostrom argued that preventing an existential catastrophe would help everyone living in the future. The number of people thus affected is so huge that even small reductions in the risks of such catastrophes are better than any action that affects only contemporary people.

Both Christians and secular thinkers direct their thoughts towards the future, but there are important differences between them. From the Christian perspective, one may say that the existence of humanity and of the world is within the power of God, not of humans, and so we cannot say how long the world will last. This argument burdens the future-oriented calculations of Bostrom with the additional risk of inadequacy. What if the apocalypse were to start tomorrow? Christians are encouraged to be ready for that event, to wait for it, and to expect it rather than the humanity lasting until the sun eventually "eats" the Earth (1 Thess. 5:2-4; 2 Pet. 3). The long-termists who encourage shaping the story of humanity's distant future do so based on the assumption that humanity can last until the end of the Earth, or maybe even until the end of the cosmos, and out of optimism regarding the quality of the lives of future people. ${ }^{33}$ These possibilities are also acknowledged by Christians, but religious people have a perspective that goes beyond earthly life with its pains and pleasures. Christians value earthly life, even one that entails more suffering than joy, as for them it is God's gift and also just a stage. It is not everything. They believe the life of the human being does not end with death. They have

33 Ord, Precipice, 20-22. 
religious reasons to not plan for the far future of earthly life. This seems to be an argument for Christians to discourage each other from accepting the logic of prioritising efforts to prevent the extinction of the human species. The Apocalypse, from the perspective of a secular thinker, might be considered a global catastrophe. For Christians, on the contrary, it is the very moment of humanity reaching its full potential, securing not only the far future but also eternity.

Are those living in the far future our neighbours, according to the less demanding interpretation of the Parable of the Good Samaritan? In thinking of who constitutes a neighbour we take as an example the wounded man. His needs were recognised by the Good Samaritan and this made him act in a compassionate way. Within the framework of "the less demanding interpretation", I argued for a broadening of the notion of the neighbour to include those people distant in space whom we can personally affect, thanks to the development of science and technology and the ensuing increase in our power. Can this be applied to future (and especially far future) people?

The first difficulty we encounter when thinking about people in the far future is the impossibility of identifying them. We can think about the next generations only in terms of estimated numbers or in terms of humanity as an abstract idea. Being unable to identify those living in the far future makes it difficult to understand how particular future people can be helped by us. In the case of animals and people living in distant countries, we can identify their needs with an accuracy not previously seen, thanks to the opportunities and capabilities of our times. But we cannot really guess what problems future people will have. Our best estimations may fail as we do not have the proper perspective. For example, we want to preserve nature for the future people. But here we are extrapolating our needs and categories. Imagine that your great grandparents did what they could to preserve their old mud hut for you. Their efforts and sacrifices would deserve respect. Yet, they would have allocated their precious resources wrongly. The world is changing very quickly and so are the values dominating society. Maybe people in the year 2200, for instance, might prefer virtual reality and not be interested in the Alps.

One very basic need we can likely think of in the case of those living in the far future is for them to have an opportunity to exist. A prerequisite for this is the further existence of our species. Although this need is so basic that thinking about it is also the outcome of the increase of our power and the development of technology. Power and technology have the potential to lead to an anthropogenic catastrophe if they are misused or even encounter 
a trivial accident. Only very recently (compared to the history of our species) has humanity acquired the ability to destroy itself (and to prevent this self-destruction). In addition, only recently has humanity learned about potential natural risks and developed the technology necessary to allow even some hope of preventing some of them. Preventing the destruction of humanity is also an opportunity of our times.

The other needs of people are dependent on their very existence. We cannot recognise the needs of those living in the far future now - this will be the task for far future Samaritans. The case of preventing the extinction of humanity may be a good example of how we can be neighbours to those living in the far future. Further, if we do not recognise this basic duty and continue acting in ways that will contribute to a potential global catastrophe, we seem to act as if we are the robbers from the Parable. And there are indeed some robbers nowadays, those who exploit the world as if it was meant only for one generation and thus contribute to the anthropogenic threats for humanity (mass destruction warfare, catastrophic climate change, environmental damage, and other risks.) ${ }^{34}$ Following the pattern of the Good Samaritan here might be interpreted as a call to mitigate the damage caused by the robbers, and therefore a call to sacrifice something for the sake of fighting the anthropogenic existential threats for humanity.

Another way of being a neighbour to those living in the far future is specifically a Christian method. Christian anthropology perceives the human being as being in a relationship with God with a specific goal to achieve - salvation. Salvation is the universal goal of all people, as well as future people. And it is a task for every Christian to help others to join the Kingdom of God. Our ancestors understood this mission well. When we were the far future generations, Christians made many sacrifices to ensure our future. They struggled to maintain, develop, and spread the Christian religion to secure our afterlife. The magnificent relics of these efforts are admired by contemporary people, even if many do not understand the purpose of the extraordinary efforts made by our ancestors. In many cases, the most solid and beautiful building in a town is its church. So often, it was built by many generations for many generations, transcending the needs and interests of a single generation. If the universal aim of human beings is salvation, and if we believe this is achieved through religion and church, we should do our best to ensure future people will have access to 
these. Being a neighbour to future people may then also mean contributing to your church now as a safeguard for the future.

There are ways to be a neighbour to the those living in the far future, although, again, this means something radically different from being a neighbour to the people in distant lands or to animals. We may now try to answer the question of if those living in the far future are our neighbours according to "the less demanding interpretation". A neighbour is someone we can personally affect. A question to be asked, then, is if we can affect those living in the far future at all. It is true that our actions and choices will have their effects in the future. Some of them will shape the far future by making it a different far future than it would otherwise be. Some opportunities will be lost forever. However, this should not be interpreted as personally affecting future people. In the same way, our generation is limited by the choices and actions of the previous generation. I suggest an analogy. Can we say that by their contribution to making the Dodo Bird or the Passenger Pigeon extinct, some people were affecting us personally? Or that the people from the past who resigned from their hunter-gatherer lifestyles and started settlements affected us personally? In those times, when we did not exist, they did not seem to be able to do it, even if they could foresee that their actions would shape the lives of the next generations.

The closer future people are to us, the more we can identify their needs, and the more pressing the metaphysical question might be: can I affect someone who does not exist yet? If yes, how can I determine if I affect them in the right or the wrong way? There are future people whose needs can be foreseen as they are close in time - like in the example of a family planning a house and their children in the nearest future. Their needs can be recognised and we can benefit them; thus, we can be neighbours to them, and so by taking the proposed less demanding interpretation it appears that some future people might be neighbours. The mere probability should be enough to warrant treating them as such.

As I argued in the part about distant people, the notion of "neighbour" does not seem to be fixed once and for all. The arrow of time inevitably brings future generations closer to us, and there is no clear border between the far future and the near future. Also, with the change of empirical circumstances and an increase of our knowledge and power, it is possible for more future people to be personally affected by us and fall into the category of neighbours.

Even if we currently find little reason to consider those living in the far future our neighbours and thus claim direct duties towards them, it does not mean the future of humanity is not a subject of concern for Christians. 
Christians have good arguments for preventing anthropogenic global catastrophes - not only those related to war, ${ }^{35}$ but also those connected with the environment, as the world was given as a means of perfection to all people, not only to the wealthy, or to one or a few generations. ${ }^{36}$ Pope Francis emphasised that the notions of the common good and solidarity also include people from the future:

\begin{abstract}
"We can no longer speak of sustainable development apart from intergenerational solidarity. Once we start to think about the kind of world we are leaving to future generations, we look at things differently; we realise that the world is a gift which we have freely received and must share with others (...) Intergenerational solidarity is not optional, but rather a basic question of justice, since the world we have received also belongs to those who will follow us." ${ }^{37}$
\end{abstract}

This reflection, made by the head of the Catholic Church, seems to include the generations from the near future: they will receive the world, as well as the duty to protect it for those generations near to them. If we are successful in preventing anthropogenic catastrophes for the forthcoming generations and passing the world (as well as the idea of intergenerational solidarity) on to them, those living in the far future will also benefit. From a Christian perspective, the mere possibility of the arrival of future people should be appreciated, and therefore "the garden" should be kept in such a condition so that future generations may use it.

The focus on the future is also a part of Christian thinking, but Christians do not abandon the present for the sake of a better tomorrow. They look towards the (eternal) future and organise their terrestrial life according to it. ${ }^{38}$ In that sense, Jesus' order "Go and do likewise" is applicable also to the those living in the far future, although what we know about them makes us focus mainly on preventing an anthropogenic global catastrophe and assuring the earthly means to salvation. On the basis of the "less demanding" interpretation of the parable, those living in the far future are not our neighbours, but it does not mean they do not count.

35 See for example John XXIII, Pacem in Terris, 109-115.

36 Francis, Laudato si', 95.

37 Ibid., 159.

38 Tischner, Nadzieja, 27. 


\section{Conclusion}

The question "who is my neighbour" is one that we still hear very often - in philosophy, in public debates, in our hearts. Global changes, including the rapid development of technology and the increase of wealth, have renewed the relevance of this question. On the basis of the proposed framework of a "less demanding" interpretation of the notion of "neighbour" from the parable of the Good Samaritan, it seems Christians have good grounds to accept the point that: our neighbours are all the people of the world. And since Christians are obliged to love their neighbours as themselves, the lives of Christians should adapt to meet this obligation. Some of the guidelines provided by EA may be used by them in order to fulfil the call from the last sentence of the parable, "Go and do likewise" (Luke 10:37), alongside the words of Pope Francis: "In the face of so much pain and suffering, our only course is to imitate the Good Samaritan. Any other decision would make us either one of the robbers or one of those who walked by without showing compassion for the sufferings of the man on the roadside." 39 The Pope encourages us to not be indifferent to suffering, even in our everyday choices, where our indifference might mean we agree to benefit from the suffering of our neighbours. ${ }^{40} \mathrm{He}$ emphasises our responsibility for the wounded men existing around the world:41 "Let us care for the needs of every man and woman, young and old, with the same fraternal spirit of care and closeness that marked the Good Samaritan." 42

The development of humanity that has occurred in recent decades and manifested itself in the progress of technology, economy, and ethics leaves little room to reject the understanding of the range of the notion of neighbour as globally applicable on the basis of the Parable of the Good Samaritan. Even the interpretation that seemed to leave a lot of room to exclude faraway people from the category of neighbours appears to broaden this notion, at least for those who are participating in this spectacular increase of wealth and opportunities.

EA goes beyond helping the poor in extreme need. In this framework, our charity efforts should also deal with the unnecessary suffering of animals and work to secure the future of humanity. The concern for animals in Christian ethics is present and has recently received more attention than

39 Francis, Fratelli Tutti, 67.

40 Ibid., 75.

41 Ibid., 77.

42 Ibid., 79. 
in the past. On the basis of the proposed reasoning, the notion of neighbour could not be broadened to include animals. This does not mean the suffering of animals is irrelevant, or one cannot be a neighbour to them, but the "love as yourself" principle was not proven to be applicable in this case.

The third cause area of EA, the case of those living in the far future, is controversial for Christians. It seems we can be neighbours to them, but here being a neighbour means doing our best to prevent an anthropogenic global catastrophe and assure access to means that help the recipient on the way to the Kingdom of God. The framework proposed in this article did not provide sufficient support for the conclusion that those living in the far future can be called neighbours, and thus must be loved as ourselves. This means re-organising life in order to provide love to the future people (as EA would propose) cannot be recommended on the basis of the provided argumentation. Obligations to the created world and already-existing people, if well understood, would, however, contribute to securing the vital interests of future people and prevent at least some of the possible anthropogenic threats to humanity.

An interesting point for further research would be considering if the three groups analysed here are the only (so-far) underestimated candidates for broadening the notion of neighbour, thanks to the opportunities of our times. I highlight one potential example as a starting point in this debate. A group that does not seem to be recognised as counting morally by many contemporary moral philosophers is that of existing (but unborn) people. We can personally affect these invisible and very vulnerable human beings for a long time before we physically see them. And again, the development of technology and ethics has changed very much in the recent years, both in our ability to be either robbers or Samaritans to them. Even if many Christians strongly oppose abortion, a genuine application of the "love as yourself" commandment would probably mean significant changes in this area, too.

The discussion surrounding the notion of neighbour in relation to the EA priorities has a potential to enrich the dialogue within the movement. EA does not say the list of priorities is exact, unchangeable, or complete. Christians interested in EA may also contribute to the process of selecting priorities. The sensibilities of Christians and Christian anthropology may suggest an understanding of good that goes beyond the material dimension and draws attention to people that are physically healthy, wealthy, and fed, yet still suffer. Are wealthy societies not full of people suffering due to the same development that equipped us with opportunities to help distant poor 
materially? Mental illness or being abandoned and lonely cause a great deal of suffering.

The notion of neighbour appears to be dynamic, and if taken within the framework of the proposed interpretation of the Parable of the Good Samaritan, I argue that within our generation understanding of this notion will be broadened significantly regarding the number of people involved. The progress of science and technology can make us acknowledge more creatures as our neighbours. Yet, what seems to be of greater importance is that this progress informs us how to "love" in a more effective way by recognising the real needs affecting people and the tools to mitigate these needs. Christians should apply this framework to neighbours, and are encouraged by Jesus to be neighbours themselves - by applying the knowledge of how to love in an effective way to other beings who can be treated as neighbours.

\section{References}

Aquinas, Thomas. Summa Theologica [ST], second and revised edition. Translated by Fathers of the English Dominican Province. London: Burns Oates \& Washbourne, 1920.

Bartosek, Antoni. "Odpowiedzialność za bliźnich w potrzebie w kontekście kategorii ordo caritatis (z uwzględnieniem problemu migracji)" [Responsibility for the neighbours in need in the context of the category ordo caritatis (including the problem of migration)]. Teologia i Moralność 12 (2017): 59-72.

Benedict XVI. Deus Caritas Est [Encyclical Letter on Christian Love]. Accessed 30 September 2021. https://www.vatican.va/content/benedi ct-xvi/en/encyclicals/documents/hf_ben-xvi_enc_20051225_deus-caritas -est.html.

Benedict XVI. Caritas in Veritate [Encyclical Letter on Integral Human Development in Charity and Truth]. Accessed 30 September 2021. https://www.vatican.va/content/benedict-xvi/en/encyclicals/documen ts/hf_ben-xvi_enc_20090629_caritas-in-veritate.html.

Bostrom, Nick. "Existential Risk Prevention as Global Priority." Global Policy 4, no.1 (2013): 15-31.

Camosy, Charles. For Love of Animals: Christian Ethics, Consistent Action. Cincinnati: Franciscan Media, 2013.

Centre for Effective Altruism. "Effective Altruism Handbook." $2^{\text {nd }}$ edition. Accessed 1 Feb 2021. https://www.effectivealtruism.org/handbook/. 
Easterly, William. The White Man's Burden: Why the West's Efforts to Aid the Rest Have Done So Much Ill and So Little Good. London: Penguin, 2006. Francis. Laudato Si' [Encyclical Letter on Care for our Common Home]. Accessed 30 September 2021. https:/www.vatican.va/content/francesco/ en/encyclicals/documents/papa-francesco_20150524_enciclica-laudato-si .html.

Francis. Fratelli Tutti [Encyclical Letter on Fraternity and Social Friendship]. Accessed 30 September 2021. https://www.vatican.va/content/fran cesco/en/encyclicals/documents/papa-francesco_20201003_enciclica-frat elli-tutti.html.

Hallett, Garth. Priorities and Christian Ethics. Cambridge: Cambridge University Press, 1998.

Hartmann, Nicolai. Ethics. Volume 2: Moral Values. Translated by Stanton Coit. London: Unwin Brothers, 1932.

John XXIII. Pacem in Terris [Encyclical Letter on Establishing Universal Peace in Truth, Justice, Charity, and Liberty]. Accessed 30 September 2021. https://www.vatican.va/content/john-xxiii/en/encyclicals/documen ts/hf_j-xxiii_enc_11041963_pacem.html.

Keener, Craig S. The IVP Bible Background Commentary: New Testament. $2^{\text {nd }}$ edition. Downer's Grove: InterVarsity Press, 2014.

Krawczyk, Roman. "Nakaz Miłości Bliźniego w Świetle Biblii. Zarys Problematyki" [The obligation to love your neighbour in light of the Bible. Introduction to the issues]. Studia Elblaskie 19 (2018): 278-290.

Leszczyński, Adam. "Eksperymenty na Biednych. Polityczny, moralny i ekonomiczny spór o to, jak pomagać skutecznie" [Experiments on the poor. Political, moral and economical dispute on how to help effectively]. Warsaw: Krytyka Polityczna, 2016.

Linzey, Andrew. Animal Theology. Chicago: University of Illinois Press, 1994.

MacAskill, William. Doing Good Better: Effective Altruism and a Radical New Way to Make a Difference. London: Guardian Books, 2015.

Ord, Toby. The Precipice: Existential Risk and the Future of Humanity. London: Bloomsbury Publishing, 2020.

Onet. "Mocne wystąpienie Kaczyńskiego ws. imigrantów. Ambasada Szwecji odpowiada." Accessed 24 March 2021. https://wiadomosci.on et.pl/kraj/mocne-wystapienie-kaczynskiego-ws-imigrantow-ambasada-szw ecji-odpowiada/zdnmqn.

Scheler, Max. The Nature of Sympathy. Translated by Peter Heath. London and New York: Taylor and Francis, 2007. 
Sider, Ronald J. Rich Christians in an Age of Hunger: Moving from Affluence to Generosity. Nashville: W Publishing, 2015.

Singer, Peter. The Expanding Circle. Oxford: Oxford University Press, 1983. Singer, Peter. The Life You Can Save: Acting Now to End World Poverty. London: Picador, 2009.

Singer, Peter. The Most Good You Can Do: How Effective Altruism Is Changing Ideas About Living Ethically. New Haven: Yale University Press, 2015.

Singer, Peter. Animal Liberation. $40^{\text {th }}$ anniversary edition. New York: Open Road Integrated Media, 2015.

Tichner, Józef. Nadzieja mimo wszystko [Hope - No Matter What]. Krakow: Znak, 2020.

Wydick, Bruce. Shrewd Samaritan: Faith, Economics, and the Road to Loving Our Global Neighbor. Nashville: W Publishing, 2019. 